\title{
What has Become Important during the Pandemic? - Reassessing Preferences and Purchasing Habits as an Aftermath of the Coronavirus Epidemic through the Eyes of Different Generations
}

\author{
Ágnes Csiszárik-Kocsir*, Mónika Garai-Fodor and János Varga \\ Óbuda University, Bécsi út 96/b, H-1034 Budapest, Hungary \\ kocsir.agnes@kgk.uni-obuda.hu*; fodor.monika@kgk.uni-obuda.hu; \\ varga.janos@kgk.uni-obuda.hu
}

\begin{abstract}
The pandemic, consumer preferences and the composition of the consumer basket changed. Each generation sees differently the impact of the virus on different areas of our lives, which is largely related to the general set of values that characterizes each generation. The focus of our research is the relationship between the generation-specific value system and the changes in consumer behaviour caused by the virus. In the primary data analysis, we focused on the examination of the consumer habits that were modified by the pandemic, the composition of the consumer basket, the customer habits, which differ for each generation and are related to the individual value system. In the light of the results, we were able to determine how the composition of the consumer basket changed, analysing, generationspecifically, which product and service purchase came to the forefront as a result of the crisis.
\end{abstract}

Keywords: financial awareness; consumer behavior; pandemic; crisis

\section{Introduction}

The 2008 crisis has taught all economic actors many lessons. We have had a much better sense of the true meaning of change, as this adverse process has had an impact on almost everyone in some form. We have learned lessons on how to manage and prevent these impacts and have experienced the changes in our daily lives as a consequence of the crisis. This was reflected, among other things, in labour markets, income trends and, not least, in our consumption habits. Following the 2008 crisis, we perhaps had no idea of the major challenges that lie ahead. After extraordinary efforts to recover around the world, markets seemed to calm down and indeed growth seemed to be sustained and expectations positive. This momentum was 
interrupted by an unexpected event, the COVID-19 pandemic, which taught humanity a new lesson in so many ways. On the one hand, we had to admit that we are still not prepared enough to respond quickly and effectively to such events. There is also much to be learned for the crisis management profession, which has seen many good and bad solutions in the past. However, it is not only in terms of crisis management methodology that we have seen important lessons. We have learned how to work from home, remotely, in areas far from our workplace. We have learnt new ways of organising work and more and more people have started to use and apply digital solutions. We have developed new habits that rely heavily on the online space, overcoming all kinds of geographical and other barriers. We have truly reorganised our lives and introduced solutions that were previously unthinkable (e.g. Home Office or regular online ordering). During the pandemic, there were fewer opportunities for offline purchases, in addition to the restrictions. It was a period that showed which products were in greater demand, which generations were able to adapt more quickly to online 'everyday life' and how the pandemic influenced and shaped our habits and behaviour today. In our study, we seek to answer the question of whether the effects of the pandemic can really be felt in areas such as consumer behaviour and shopping habits. To this end, we have sought to identify the main factors influencing consumer behaviour. Drawing on previous literature and research, we have identified various variables that influence consumer behaviour. This is summarised in Figure 3. We consider globalisation to be important because it has enabled the expansion of international trade, the broadening of the consumption structure and the spread of new products and services around the world. Given that globalisation is a long-standing process, we felt it important to mention the impact of globalisation in the study and link it to changes in consumer behaviour. We have come to the emergence of a global consumer culture, to which many are becoming attached while others are becoming resistant. However, in addition to globalisation, we also had to consider other aspects. One is the impact of the pandemic, which makes the subject of this study extremely topical. The impact of COVID-19 can be seen in all aspects of life, and has of course had a significant impact on consumer behaviour, which will be examined in a separate section. Given that digital solutions have become more widespread as a result of the crisis event, it was of great interest to see which generation could adapt best. Also, which generation would experience the biggest changes in consumer preferences. Additionally, there was a need to take generational characteristics into account since it was strongly suspected that different generations would not adapt in the same way. It was also interesting to see how similar or different they were in terms of changes in consumer behaviour. Taking all these factors together, the research results that are presented in this paper have been developed. Looking at existing changes (e.g. the impact of COVID-19) and trends (globalisation, digitalisation), it is safe to say that further research on consumer behaviour will be much needed in the future. The pandemic and the crisis have a long-term impact on our habits and behaviour. 


\section{Literature Review}

\subsection{The Emergence of a Global Consumer Culture}

Globalization is one of the most powerful shaping factors in our lives. Different views have emerged about the origins and characteristics of this process [1]. Globalization is interpreted in very different ways by different experts [2] who point out that there are many definitions of globalization, making it even more difficult to agree on its origins or measurement [3]. For the purpose of this paper, the definition of globalization is not the main objective, but it is important to mention its role in shaping consumer behavior. All this can be understood in an indirect way. After World War II, both international trade and world GDP volumes increased significantly. This is due to the fact that the GATT Agreement signed after World War II and the free trade and preferential agreements established along the way brought countries and economic operators closer together than ever before [4]. They have successfully removed many of the trade policy barriers that had hitherto hindered the growth of international trade (this was the impact of the GATT Agreement, as the reduction of tariffs has contributed significantly to the expansion of trade, and thus the emergence of new products in new markets). Moreover, since the 1960s, the number of multi- and transnational corporations (MNCs, TNCs ) has soared, taking advantage of the gradual dismantling of barriers to international trade to expand consumption opportunities by creating trade and substitution in many areas of the world [5]. In 1995, there were only 38,541 transnational corporations, while by 2010 (in just 15 years) the number had risen to 103,786 [6]. The UNCTAD World Investment Report provides evidence of the changing number of multi and transnational corporations [7]. By internationalizing their supply chains, these companies have made the purchasing options available to consumers more colorful and diverse than ever before [8]. Consumption options have expanded, fundamentally reordering consumers' choice preferences. International trade has enabled us to consume more than ever before, as we did in previous decades or centuries. We have been introduced to products we had never heard of before. The process of globalization and the development of the market economy has created a consumer culture in which people are trying to satisfy their consumer needs as best they can [9]. Mass culture influences consumer behavior and its evolution and preferences. Globalization leads to structural changes in the economy and changes consumer preferences. This manifests itself as people in developing countries start to follow the consumption patterns of more developed countries [10]. Indeed, an important step in this process is to familiarize the population of less developed countries with the new consumption options. Here, international supply chains, large corporations and the breaking down of trade barriers have played a significant catalytic role, since one way of learning about new products is precisely by breaking into a new market. The rapid development of data innovation can also be highlighted. Previously unknown brands can also quickly become popular through media and new channels, so the spread of international companies is not 
the only reason for the change in consumer habits. However, globalization can be seen to be causing changes in the economy and altering consumer tastes and lifestyles. This change in lifestyle is also responsible for the change in consumer habits [11]. The reason for this can be seen in the fact that globalization is fundamentally changing people's values, beliefs and behavior, which will affect their consumption behavior [12]. Nowadays, people have many more opportunities to learn about other cultures and customs (e.g. through travel, ICT, etc.), which may later influence their behavior and subsequently their purchasing decisions. It is clear that consumers are influenced by a variety of foreign and domestic products. They are constantly exposed to media, brand and cultural influences and these subsequently influence consumer decisions [13]. Globalization has also paved the way for the free flow of products, the unrestricted spread of information or the proliferation of media. The authors discuss the emergence of a global consumer culture, in which certain consumer segments share similar characteristics, regardless of where they are located in the world. The notion of homogeneous groups of buyers and customers has emerged, while some people can now form cultural communities based on their consumption habits. It can be said that we can now belong to a culture on the basis of our buying habits or consumer behavior (e.g. the Apple buying group). The emergence of the concept of global consumer culture (GCC) is a good illustration of the link between globalization and consumer behavior. Global consumer culture has a much broader meaning as it is not limited to a single country. Local cultures are permeated by international capital (see earlier on the role of multinational corporations), global information technologies and the impact of the media (now mainly in the online space) [14]. However, globalization has not only been able to have a profound impact on people's consumer preferences. In additon, creating homogeneous consumer groups and creating a global consumer culture, globalization has also brought nation states closer together than ever before, so that they are indeed interdependent, not just in terms of consumer habits. Unfortunately, the latter has also facilitated the spread of the pandemic, as there are no longer any major barriers to the free movement of people.

\subsection{Exogenous and Endogenous Dimensions of Consumer Behaviour}

Consumer behavior, as part of human behavior, is a complex and complicated process, and it is no coincidence that its study has been a major focus of marketing for decades. Knowledge of consumer behavior and the purchase decision process is essential for developing a competitive marketing concept and portfolio of products and services that meets current expectations [15]. In order to create an attractive offer that is appealing to the customers, it is important to understand how they make their decision and the processes and mechanisms behind the decisions [16], [17]. According to the interdisciplinary approach to consumer behavior, consumer behavior is a complex behavior that involves individual needs, the determinants of one's environment, the information available to the buyer, the ability to evaluate 
alternatives and the decision mechanism that subsequently satisfies or dissatisfies the customer. According to the schematic model of consumer choice (Figure 1), in addition to the effects of the familiar (endogenous) factors that are linked to the consumer, the influence of the wider environment (exogenous dimensions) that are independent of the consumer is also taken into account [18].

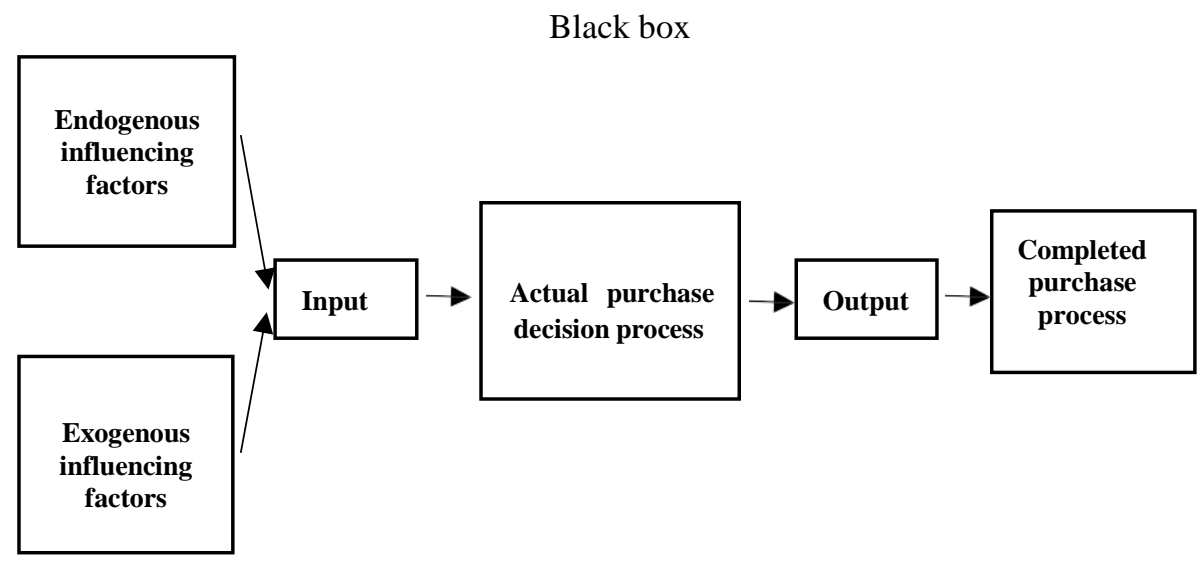

Figure 1

Schematic diagram of the consumer-customer decision process

Source: authors' own edition based on [61]

In our study, we focus on both endogenous and exogenous dimensions: in the latter case, we analyze the role of the coronavirus crisis as a multidimensional macrofactor that influences consumer behavior. As for the former, i.e., endogenous factors, we focus on generation-specific characteristics. In addition, the role of individual value orientation in the basic context of value-based models of consumer behavior is examined in order to gain a more nuanced understanding of individual consumer choice.

\subsection{Impact of the COVID-19 Epidemic}

Today, not only globalization, but also other globalizing processes are having a significant impact on shopping habits. The most recent of these is the COVID-19 pandemic, which has affected every aspect of our lives. We have changed our habits, our purchasing preferences and have sought more conscious ways to meet our needs [19]. Our shopping habits have changed and we have adapted to the new situation. The ban and restriction on visiting shops increased the traffic to online shops, i.e. the shop came to us [20]. Other aspects of adapting to new challenges are being further modified by digitalization, the spread of innovative solutions and the blurring of work-life boundaries, creating a new world of consumption. We have witnessed purchasing phenomena that are unusual in the modern world, but which have not been present in previous welfare societies and models in the recent past. 
Panic buying, shocks caused by often unsubstantiated information generated by online sources has been repeatedly observed during the pandemic period [21].

The COVID-19 pandemic has fundamentally changed our perceptions not only in the workplace (Home Office) (we used to think that our work was only available from our workplace). There has also been a paradigm shift in commerce, finance and shopping. Our consumption patterns are fundamentally shaped by four contexts [20]. The first is the social context, in which life events, marriage, family, having children or moving house, occur. It also includes the workplace, which can also influence our purchasing decisions. The second context is technology. In recent years there have been a number of technological breakthroughs. Just think of the emergence of smart devices. They have radically changed our habits and therefore our purchasing preferences. It has also given way to a new era of shopping, online and digital. In the third context are the rules and regulations that can appear, for example, in public spaces, in public places. Alongside these, the fourth context is just as important, covering ad hoc, ad hoc phenomena or natural disasters. Examples include earthquakes, hurricanes, civil wars and, of course, the COVID-19 pandemic, which is still having an impact, not only on consumer behavior [20]. The pandemic has created an opportunity for retail to open up new opportunities. Customers have recognized the importance of retail in their daily lives [22]. During the pandemic, shopping baskets changed, the routine of running a household changed, the reasons for shopping and the availability of goods and services changed. The COVID-19 epidemic has also fundamentally affected the retail sector [23]. Countries had to diversify their trade to mitigate external shocks. People behave fundamentally differently during a negative event, as they are not all the same. In times of crisis, new trends in consumer behavior emerge. The main factors are crisis behavior, risk attitude and risk perception. Risk attitude reflects the consumer's interpretation of the content of the risk, while risk perception reflects the consumer's interpretation of how much exposure to risk he or she feels [24].

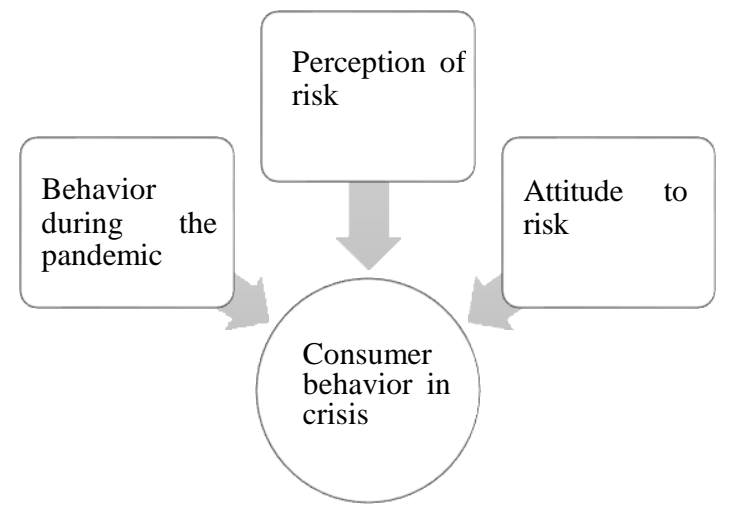

Figure 2

Components of consumer behavior during the crisis

Source: authors' own editing based on [62] 
The impact of the crisis on consumer behavior has been described by some as critical. Crises can facilitate certain trends while others are completely slowed down and disappear. In general, consumer demand is for simplicity [25]. The process of digitalization that started before the pandemic, the hunger for information and the demand for information before the pandemic, opened up many new channels, with consumers looking for information that did not always give the truth. The distorted and false information triggered shocks in consumers due to artificially inflated fears. This shock was different from the others. Fear of loss of income, the expected disruption of supply chains, mobilized basic human motivations [26]. Although governments have tried to mitigate panic with bailouts, replacement of lost income, subsidies and other benefits, the phenomenon of panic buying among consumers has emerged from time to time [27]. In addition to panic buying, another well-observed phenomenon in similar situations is the restraint in spending by consumers, which is influenced by product categories, age, marital status, gender, place of residence and family structure [28], [29], [30]. In general, consumers are looking for value-oriented products and services that simplify their lives. The results of research by major market research organizations (BCG, KPMG, Deloitte) summaries the impact of the COVID19 epidemic on consumer behavior [24]. All studies agreed that there is clear evidence of changes in consumer behavior. According to BCG, low-income and younger consumers showed a greater propensity to plan to reduce their spending [31]. However, KPMG also highlights that consumers have become more aware [32]. Consumers were also more attentive to price, origin and usefulness of products. Joining the previous organizations, Accenture came to the same conclusion. The latter mentions that consumer habits have not only changed in terms of awareness as a result of the coronavirus epidemic, but also that demand for certain products (such as hygiene products) has increased [33]. The epidemic has affected access to and purchasing behavior of food. Shopping trips, stocking and online shopping behavior have decreased [34]. The pattern of food consumption has also changed for different age groups. Some of the population started to eat more healthily and consciously, while others did so less [35] with increased snacking and less healthy food consumption [34]. Research by Accenture, KPMG and BCG confirms the emergence of awareness [31], [32], [33]. Following the COVID-19 epidemic, demand for some products increased, while others declined. The latter category includes clothing or luxury products. However, there is a clear increase in demand for durable food and health-related products. In addition, international market research organizations have also pointed out that changes in consumer behavior should be analyzed by age group and income level. The emergence of online and digital tools in the shopping process is of great importance [36]. However, it is also worth noting that while online solutions have been of significant help during the COVID-19 pandemic, they will not be able to fully replace physical shopping. For example, online stores will not be able to meet all consumer needs in the same way as traditional (offline, physical) stores. In fact, digital shopping does not allow the customer to touch, see and feel the quality of the product in person, which is an important part of the shopping process [36]. The study of consumer behavior is made even more nuanced by the fact that different 
age groups in society also exhibit different consumer behavior. Income is not the only determinant, but it is important to look at the attitudes of different age groups and generations towards consumption and shopping. It is not difficult to see that economic globalization has contributed significantly to changing consumption patterns. International firms and global supply chains have expanded consumption opportunities, but the COVID-19 pandemic has also highlighted the continuing importance of retailing. In addition, we should also see that globalization is not the only factor in changing consumer behavior, as the aforementioned contexts, social age groups and natural disasters or pandemics can also change our preferences [20]

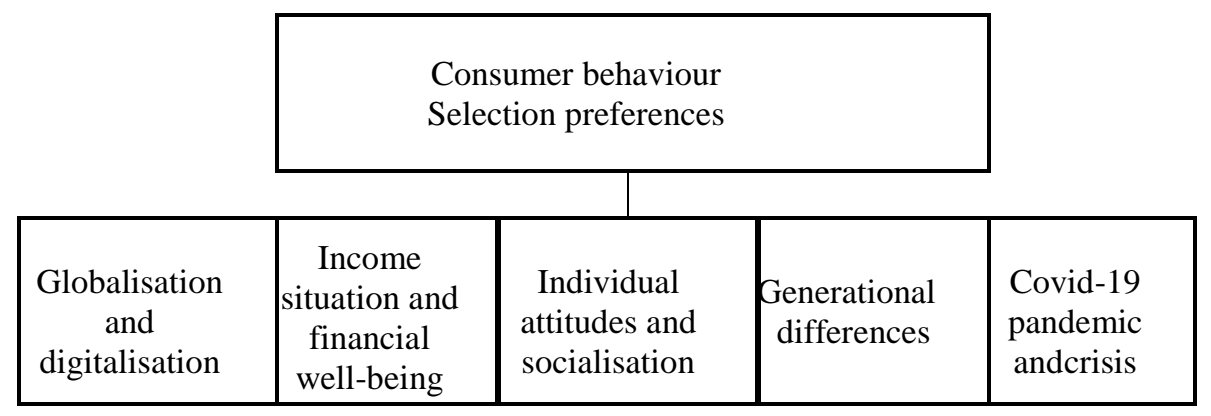

Figure 3

Megatrends that shape consumer behavior in 2021

Source: authors' own editing

\subsection{The Role of Generational Differences in Consumer Choices}

Generational differences have been successfully used as a segmentation criterion in marketing in many areas, as each generation is a bearer of differences that can be well characterized by common values, mindsets and behaviors that are specific to them. Values, shared experiences, are a sort of organizing principle and the identities found within generations frame the decisions of the people belonging to them and distinguish them from other generations [37]. The differences between generations, generational traits, go beyond simple age specificities. A generational approach is not equivalent to age segmentation. It is a more complex approach since the major events of the years they have lived through together - social, technological, cultural, etc. shape those born at different times into generations with specific characteristics. These shared experiences and life experiences shape each generation, forming their specific consumer habits, mindsets and values. In our primary research, we touch on the baby boomer, generations $\mathrm{X}, \mathrm{Y}$, and $\mathrm{Z}$, so we will describe in a few sentences the main general and consumer characteristics that characterize them. It is important to note that there is a lot of variation in the literature regarding the birth years of the people belonging to each generation, so not all age categories mentioned by the experts in the study show a complete overlap with the age of the subjects of the primary research. 
Members of the baby boomer generation are important for them to build relationships. Members of this generation rejected their parents' rigid moral concepts, created a new culture for themselves, sought peace and greater freedom, and became more tolerant and curious than their predecessors. They are also committed and loyal customers who are not afraid of new challenges. They are slower to adapt to change, which explains the tension that often exists between them and younger generations [38].

Generation $\mathrm{X}$ is also referred to as the transition generation, as their value's reflect the older generation's respect for status, work and achievement, but also the need to develop as individuals, the preference for status symbols and the need for selfreward [39]. Generation X have already encountered the internet as almost adults, they see its benefits, they experience it as a privilege. They see how much easier it makes life, but it is not the only reality for them. They are able to take advantage of the benefits and turn them to their advantage [40]. Generation X has become perfectionists as a result of experiencing a deficit economy. In their childhood, almost everything was a scarcity item, members of Generation X experienced a deficit in communication tools, and this gives Generation Xers a special attitude [41]. This is the generation characterized by one of the greatest adaptability. This is no different in the field of shopping: they have adapted quickly to technological advances and represent one of the largest customer bases for online purchases [42].

Looking at the consumption habits of Generation Y, they are looking for novelty, new experiences and impulse buying. They prefer personalized options, convenience and flexibility in their decisions [43]. Generation Y members are already skeptical about digitalization and try to protect and limit their children from excessive internet use. They are immature about the opportunities offered by digitalization, they are wary of their data, they are not easily led in exchange for a discount or two. The dividing line between the two generations is 1995 , which also marks the beginning of the Internet era [44]. Among the general characteristics of Generation Y, the literature mentions a strong social sensitivity alongside ambition and innovativeness. This generation is particularly keen on monitoring corporate social responsibility and is characterized by a "green consumerism" [45]. Another good characteristic of Generation Y members is considered by experts to be their love of shopping. It is no coincidence that many CRM and customer loyalty programs focus on this generation [46].

For Generation Z, shopping is an experience, and their consumption habits reflect the self-rewarding nature of this generation, they look for promotions and discounts, and like Generation $\mathrm{Y}$, they prefer personalized offers. Generation $\mathrm{Z}$ are born into the online world, and have grown up with social media. The world is almost in their room, in the form of television, computer or even smartphones. One of the characteristics of this generation is their preference for online shopping, much more so than among the non-net generation. Adding to this, online shopping is now a growing form of shopping regardless of generation [47], which was particularly amplified by COVID-19. This fact is related to the generation's consumer 
characteristics, given that in many cases they are more confident in moving in the online space than in reality [48]. If they need something, they can access it quickly and conveniently in the online world, which they perceive as much safer than the real world. This generation is referred to by various adjectives: bit generation, net generation (N-generation), D-generation (digital), but they are also called digital natives [49]. Due to the general hedonism that characterizes Generation Z, having children is postponed and they stay longer. In many cases, the focus on the individual, on self-interest, brings to the surface narcissistic characteristics that will affect their attitude towards work and even society [50]. A closer look at generations provides an opportunity to define habits more precisely, to understand why, when and how customers are likely to act. This is why we focus on this endogenous factor of consumer behavior analysis, in addition to an overview of global trends and the macro-environmental impact of the aging virus. Understanding the generational isms that are linked to the consumer gives us the opportunity to understand more precisely the motives and indicators behind consumer behavior and thus to offer marketing solutions that are even better adapted to consumer needs.

\section{Material and Method}

In this paper, we present a systematic review of relevant national and international literature and present partial results of our primary research. The primary data collection took place between May and October 2020, and involved quantitative research: a pre-tested, standardized online questionnaire survey. Subjects were recruited through a snowball sampling procedure, using our own active students as the first base, by sharing the online research tool directly to their email address. Subjects were recruited using a snowball sampling procedure, resulting in 6804 evaluable questionnaires. The research tool consisted exclusively of closed questions at nominal measurement level (single-choice and multiple-choice questions) and metric scales (Likert scale and semantic differential scale) to analyze consumer attitudes and values. The topics of the research tool were developed as a result of relevant secondary data analysis. Each response alternative - pre-testing of the research tool - was finalized in the light of qualitative results. In the framework of this qualitative research phase, 10 mini-focus group interviews were conducted, in which the subjects were also selected using the snowball method, with our own active students as the sampling frame. The call for qualitative research was distributed among them and the first ten respondents remained in the final sample, and the snowball sampling technique continued with their inclusion until the final number of interviewees was reached.

The mini focuses were guided group discussions with 3-4 participants each, with a heterogeneous composition in terms of gender and age. The main objective of the qualitative research was to establish the quantitative research, finalize the standardized questionnaire and outline the research hypotheses. 
In the qualitative phase, a semi-structured guide was used, the main topics of which were: knowledge and perception of the different crises, analysis of the impact of the coronavirus crisis on consumer behavior, the impact of the crises on the perception of competences (what knowledge and skills have been revalued as a result of the crises. In a separate theme, we analyzed the different banking services, banking preferences and the demand for digital banking services, which formed the basis for the analysis of customer preferences independent of the impact of the crises.

The qualitative phase resulted in a finalized quantitative research tool. The standardized questionnaire consisted of a total of questions 28 and covered the following topics: perception of crises, analysis of the impact of crises in the light of perceptions of digital skills, economic knowledge and management competences, bank choice and loyalty to the service provider - conditions for staying in the bank. Only closed questions were used in the questionnaire, at nominal (selective, decisive, combinatorial) and metric Likert and semantic differential scale, ratio scale) levels of measurement.

In this paper we focus on the partial results of the quantitative phase of our research project. Within that, we have also given priority to the analysis of the impact of crises, the examination of the relationship between the perception of crises and the financial education of the subjects.

The quantitative results were processed using descriptive statistics, bivariate and multivariate analyses using SPSS 22.0 software. In the present study, in addition to descriptive statistics, the analysis of variance method was used to examine the correlation between nominal and metric scale scores, including the one- way ANOVA method for comparing multiple sample means. The mean of a metric dependent variable was compared between more than two groups. The post-hoc test was used to determine which pairs of groups differed significantly. Significance values were used to determine the existence of correlations ( $\mathrm{sig}<=0.005$ ). Internal correlations were analyzed along the comparison of group means using the F- statistic, i.e., the coefficient of variance of the means within samples [51], [52].

For the correlation tests presented in the study, where the significance value according to the ANOVA table was below 0.05, it was confirmed that there is a correlation between the age group (generation) and the variable under study (average value of the change in the use of products and services), so these data were highlighted and illustrated in the SPSS post-hoc test results.

During the quantitative research phase, our main objective was to analyze the following hypotheses:

H1: The impact of the coronavirus has led to statistically verifiable changes in consumer habits and the composition of the consumer basket;

H2a: Buying habits differ between the generations studied;

$\mathrm{H} 2 \mathrm{~b}$ : Buying habits are also related to individual values. 
The logical framework for the presentation of the partial results presented in this paper is the evaluation of the hypotheses mentioned above.

The main socio-demographic characteristics of the sample are as follows: $50.6 \%$ of the 6804 respondents were male and $49.4 \%$ female. Only $7.2 \%$ of the respondents have elementary education, $57.2 \%$ secondary education, $26.3 \%$ have a bachelor's degree and $9.3 \%$ have a master's degree. In terms of age, the largest share of the sample (39.4\%) is from Generation Z (18-25 years). They were followed by $21.8 \%$ of respondents aged $26-35$ and $17 \%$ of respondents aged 36-45. Respondents aged 46-55 years represented $13.1 \%$ of the sample, while respondents aged 55 years represented only $8.5 \%$ of the sample. As our research hypothesis suggests that there is a statistically verifiable correlation between financial and economic education and perceptions of the crisis, we consider it important to characterize our sample along this criterion. More than half of our respondents (57.1\%) have no previous economic-financial education, with such knowledge characterizing $57.1 \%$ of our respondents.

\section{Results}

To test the $\mathrm{H} 1$ hypothesis, a separate set of questions analyzed the consumer behavior of the sample members in terms of changes in their shopping habits caused by the epidemic situation. The results show that the proportion of durable food and health food products in the respondents' shopping baskets increased the most as a result of the coronavirus outbreak.

Table 1

Changes in personal consumption in response to the coronavirus epidemic 1

\begin{tabular}{|l|l|l|l|l|l|l|l|}
\hline & $\begin{array}{l}\text { clothing } \\
\text { items }\end{array}$ & $\begin{array}{l}\text { durable } \\
\text { food }\end{array}$ & $\begin{array}{l}\text { daily } \\
\text { consumer } \\
\text { goods } \\
\text { (bread, } \\
\text { dairy } \\
\text { products) }\end{array}$ & medicine & $\begin{array}{l}\text { health } \\
\text { preservatives }\end{array}$ & $\begin{array}{l}\text { consumer } \\
\text { durables } \\
\text { (technical } \\
\text { and other } \\
\text { goods) }\end{array}$ & $\begin{array}{l}\text { culture, } \\
\text { entertainment }\end{array}$ \\
\hline Mean & 2,01 & 2,97 & 2,83 & 2,80 & 2,88 & 2,38 & 2,14 \\
\hline St.dev. & 0,95 & 0,86 & 0,86 & 0,92 & 0,90 & 0,97 & 1,02 \\
\hline
\end{tabular}

In addition to the impact of the coronavirus epidemic on FMCG (fast moving consumer goods) and consumer durables purchases, we also analyzed its impact on the tertiary sector. Overall, the results show that the service sector suffered a fairly big loss in the pandemic, as there was no type of service that did not experience a drop in demand. The largest declines were recorded in frequenting larger clothing stores, smaller grocery stores and large shopping centers as well as restaurants.

1 average where 1 = greatly decreased, $4=$ greatly increased 
Table 2

Frequency of use of certain services

\begin{tabular}{|l|r|r|r|}
\hline $\begin{array}{l}\text { Average, where } \\
\mathbf{1}=\text { greatly decreased; } \\
\text { 4= greatly increased) }\end{array}$ & $\begin{array}{c}\text { Frequency before } \\
\text { corona-virus } \\
\text { (average) }\end{array}$ & $\begin{array}{c}\text { Frequency after } \\
\text { corona-virus } \\
\text { (average) }\end{array}$ & $\begin{array}{c}\text { Difference } \\
\text { between averages } \\
\text { in absolute terms }\end{array}$ \\
\hline bank branches & 2.66 & 2.51 & 0.15 \\
\hline large shopping centres & 3.29 & $\mathbf{3 . 0 4}$ & $\mathbf{0 . 2 5}$ \\
\hline small food shops & 3.36 & $\mathbf{3 . 1 1}$ & $\mathbf{0 . 2 6}$ \\
\hline larger clothing stores & 3.22 & $\mathbf{2 . 9 3}$ & $\mathbf{0 . 2 8}$ \\
\hline $\begin{array}{l}\text { small clothing shops, } \\
\text { boutiques }\end{array}$ & 3.12 & 2.93 & 0.19 \\
\hline larger technical stores & 3.10 & 2.89 & 0.21 \\
\hline small technical shops & 3.00 & 2.86 & 0.14 \\
\hline insurance companies & 2.66 & 2.60 & 0.06 \\
\hline travel agencies & 2.61 & 2.56 & 0.05 \\
\hline restaurants & $\mathbf{3 . 1 4}$ & $\mathbf{2 . 9 0}$ & $\mathbf{0 . 2 5}$ \\
\hline cookery shops & 3.05 & 2.84 & 0.21 \\
\hline bakeries & 3.12 & 2.90 & 0.22 \\
\hline pharmacies, health & 3.26 & 3.08 & 0.18 \\
\hline shops & 3.05 & 2.85 & 0.20 \\
\hline $\begin{array}{l}\text { beauty service } \\
\text { providers }\end{array}$ & & Source: authors' own research 2020, N=6804 \\
\hline
\end{tabular}

While certain product groups were the clear winners of the epidemic - due to their increased purchase volume during the epidemic - the services under review all experienced a drop in customer interest (hypothesis H1 confirmed). In line with the hypothesis testing, we also analyzed the individual changes in consumer behavior on a generation-specific basis: we looked at the products and services whose frequency and extent of use after the epidemic were related to the age of the sample member. The results of the correlation analysis between the extent of purchase of products and age categories showed that for the exception of health promotion products, a significant difference ( $\mathrm{sig}=0.008$ ) was found between the extent of purchase of the product and the age of the respondent for each product group $(\operatorname{sig}<0.005)$. (Hypothesis $\mathrm{H} 2$ /a confirmed).

For our Generation $\mathrm{Z}$ respondents (18-25 years old), we found that purchases of clothing, daily consumer durables and consumer durables, as well as durable food increased at a higher rate than the sample average and other age groups. For clothing and consumer durables, as well as for education and entertainment, members of Generation Y (26-35 years) represented the largest consumer base. While, unsurprisingly, consumption of medicine was higher than the sample average among older respondents aged 56-65. 
Á. Csiszárik-Kocsir et al. What has Become Important during the Pandemic? - Reassessing Preferences and Purchasing Habits as an Aftermath of the Coronavirus Epidemic through the Eyes of Different Generations

Table 3

Consumption patterns in relation to age in the context of the coronavirus epidemic ${ }^{2}$

\begin{tabular}{|c|c|c|c|c|}
\hline & & $\mathrm{N}$ & Average & $\operatorname{sig}$ \\
\hline \multirow[t]{7}{*}{ clothing items } & $18-25$ years & 2688 & 2,04 & 0,000 \\
\hline & 26-35 years & 1490 & 2,10 & \\
\hline & $36-45$ years & 1156 & 2,08 & \\
\hline & $46-55$ years & 882 & 1,89 & \\
\hline & $56-65$ years & 349 & 1,84 & \\
\hline & above 65 years & 239 & 1,90 & \\
\hline & sample & 6804 & 2,02 & \\
\hline \multirow[t]{7}{*}{ durable food } & 18-25 years & 2688 & 3,04 & 0,000 \\
\hline & 26-35 years & 1490 & 2,93 & \\
\hline & $36-45$ years & 1156 & 2,88 & \\
\hline & $46-55$ years & 882 & 3,01 & \\
\hline & $56-65$ years & 349 & 3,02 & \\
\hline & above 65 years & 239 & 2,89 & \\
\hline & sample & 6804 & 2,98 & \\
\hline \multirow{7}{*}{$\begin{array}{l}\text { daily consumer goods } \\
\text { (bread, dairy products) }\end{array}$} & 18-25 years & 2688 & 2,90 & 0,000 \\
\hline & 26-35 years & 1490 & 2,79 & \\
\hline & $36-45$ years & 1156 & 2,85 & \\
\hline & $46-55$ years & 882 & 2,76 & \\
\hline & $56-65$ years & 349 & 2,81 & \\
\hline & above 65 years & 239 & 2,67 & \\
\hline & sample & 6804 & 2,84 & \\
\hline \multirow[t]{7}{*}{ medicine } & 18-25 years & 2688 & 2,87 & 0,001 \\
\hline & 26-35 years & 1490 & 2,80 & \\
\hline & $36-45$ years & 1156 & 2,76 & \\
\hline & $46-55$ years & 882 & 2,76 & \\
\hline & $56-65$ years & 349 & 2,91 & \\
\hline & above 65 years & 239 & 2,83 & \\
\hline & sample & 6804 & 2,82 & \\
\hline \multirow{5}{*}{$\begin{array}{l}\text { consumer durables } \\
\text { (technical and other goods }\end{array}$} & 18-25 years & 2688 & 2,45 & 0,000 \\
\hline & 26-35 years & 1490 & 2,43 & \\
\hline & $36-45$ years & 1156 & 2,39 & \\
\hline & $46-55$ years & 882 & 2,20 & \\
\hline & 56-65 years & 349 & 2,24 & \\
\hline
\end{tabular}

2 average where 1 = greatly decreased, 4 = greatly increased 


\begin{tabular}{|c|c|c|c|c|}
\hline & above 65 years & 239 & 2,36 & \\
\hline & sample & 6804 & 2,39 & \\
\hline culture, & $18-25$ years & 2688 & 2,15 & 0,000 \\
\hline entertainment & 26-35 years & 1490 & 2,23 & \\
\hline & $36-45$ years & 1156 & 2,16 & \\
\hline & 46-55 years & 882 & 2,01 & \\
\hline & 56-65 years & 349 & 2,08 & \\
\hline & above 65 years & 239 & 2,17 & \\
\hline & sample & 6804 & 2,15 & \\
\hline
\end{tabular}

Source: authors' own research 2020, N=6804, analysis of variance, measurement levels: nominal and metric scale

A significant difference ( $\operatorname{sig}<0.005)$ was found between age groups for all services for all alternatives examined. For bank branches, the biggest drop in service was observed for respondents belonging to Generation Z. However, it was members of this generation who accounted for the majority of visitors to large shopping centers, smaller grocery stores and especially restaurants during the coronavirus outbreak. For our Generation Y respondents (26-35-year-olds), this was the case for restaurants. The results show that Generation X (36-45 years old) became the main customers in the tertiary sector during the outbreak, with members of this generation showing the highest purchasing power and the most frequent use of beauty services, travel agencies, insurance companies, bakeries and technical shops. By contrast, for customers aged 65 and over, the overall trend was a drop in the frequency of use of all services in their age group as a result of the epidemic. This is presumably because they may have felt most vulnerable to the negative effects of the epidemic.

Table 4

Patterns of use of post-epidemic services for coronavirus by age ${ }^{3}$

\begin{tabular}{|c|c|c|c|c|}
\hline & & $\mathrm{N}$ & Average & sig \\
\hline \multirow[t]{7}{*}{ bank branches } & 18-25 years & 2688 & 2,36 & 0,0000 \\
\hline & 26-35 years & 1490 & 2,63 & \\
\hline & $36-45$ years & 1156 & 2,63 & \\
\hline & $46-55$ years & 882 & 2,59 & \\
\hline & $56-65$ years & 349 & 2,53 & \\
\hline & above 65 years & 239 & 2,56 & \\
\hline & sample & 6804 & 2,51 & \\
\hline \multirow[t]{5}{*}{ large shopping centres } & $18-25$ years & 2688 & 3,08 & 0,0041 \\
\hline & 26-35 years & 1490 & 3,03 & \\
\hline & $36-45$ years & 1156 & 3,05 & \\
\hline & 46-55 years & 882 & 3,04 & \\
\hline & $56-65$ years & 349 & 2,90 & \\
\hline
\end{tabular}

3 average where 1 = greatly decreased, 4 = greatly increased 


\begin{tabular}{|c|c|c|c|c|}
\hline & above 65 years & 239 & 2,90 & \\
\hline & sample & 6804 & 3,04 & \\
\hline \multirow[t]{7}{*}{ small food shops } & $18-25$ years & 2688 & 3,15 & 0,0293 \\
\hline & 26-35 years & 1490 & 3,07 & \\
\hline & $36-45$ years & 1156 & 3,09 & \\
\hline & 46-55 years & 882 & 3,19 & \\
\hline & 56-65 years & 349 & 3,00 & \\
\hline & above 65 years & 239 & 2,80 & \\
\hline & sample & 6804 & 3,11 & \\
\hline \multirow{7}{*}{$\begin{array}{l}\text { small clothing shops, } \\
\text { boutiques }\end{array}$} & $18-25$ years & 2688 & 2,93 & 0,0000 \\
\hline & 26-35 years & 1490 & 2,92 & \\
\hline & $36-45$ years & 1156 & 2,96 & \\
\hline & $46-55$ years & 882 & 2,98 & \\
\hline & 56-65 years & 349 & 2,85 & \\
\hline & above 65 years & 239 & 2,77 & \\
\hline & sample & 6804 & 2,93 & \\
\hline \multirow[t]{7}{*}{ larger technical stores } & $18-25$ years & 2688 & 2,85 & 0,0212 \\
\hline & 26-35 years & 1490 & 2,93 & \\
\hline & $36-45$ years & 1156 & 2,92 & \\
\hline & $46-55$ years & 882 & 2,95 & \\
\hline & 56-65 years & 349 & 2,81 & \\
\hline & above 65 years & 239 & 2,83 & \\
\hline & sample & 6804 & 2,89 & \\
\hline \multirow[t]{7}{*}{ small technical shops } & $18-25$ years & 2688 & 2,84 & 0,0155 \\
\hline & 26-35 years & 1490 & 2,87 & \\
\hline & $36-45$ years & 1156 & 2,94 & \\
\hline & $46-55$ years & 882 & 2,85 & \\
\hline & 56-65 years & 349 & 2,82 & \\
\hline & above 65 years & 239 & 2,73 & \\
\hline & sample & 6804 & 2,86 & \\
\hline \multirow[t]{7}{*}{ insurance companies } & $18-25$ years & 2688 & 2,56 & 0,0000 \\
\hline & 26-35 years & 1490 & 2,67 & \\
\hline & $36-45$ years & 1156 & 2,71 & \\
\hline & $46-55$ years & 882 & 2,53 & \\
\hline & 56-65 years & 349 & 2,51 & \\
\hline & above 65 years & 239 & 2,52 & \\
\hline & sample & 6804 & 2,60 & \\
\hline \multirow[t]{4}{*}{ travel agencies } & $18-25$ years & 2688 & 2,51 & 0,0000 \\
\hline & 26-35 years & 1490 & 2,65 & \\
\hline & $36-45$ years & 1156 & 2,66 & \\
\hline & $46-55$ years & 882 & 2,52 & \\
\hline
\end{tabular}




\begin{tabular}{|c|c|c|c|c|}
\hline & 56-65 years & 349 & 2,47 & \\
\hline & above 65 years & 239 & 2,46 & \\
\hline & sample & 6804 & 2,56 & \\
\hline \multirow[t]{7}{*}{ restaurants } & $18-25$ years & 2688 & 2,94 & 0,0000 \\
\hline & 26-35 years & 1490 & 2,91 & \\
\hline & $36-45$ years & 1156 & 2,91 & \\
\hline & $46-55$ years & 882 & 2,89 & \\
\hline & 56-65 years & 349 & 2,69 & \\
\hline & above 65 years & 239 & 2,55 & \\
\hline & sample & 6804 & 2,90 & \\
\hline \multirow[t]{7}{*}{ cookery shops } & $18-25$ years & 2688 & 2,84 & 0,0018 \\
\hline & 26-35 years & 1490 & $\mathbf{2 , 8 8}$ & \\
\hline & $36-45$ years & 1156 & 2,87 & \\
\hline & $46-55$ years & 882 & 2,82 & \\
\hline & 56-65 years & 349 & 2,72 & \\
\hline & above 65 years & 239 & 2,64 & \\
\hline & sample & 6804 & 2,84 & \\
\hline \multirow[t]{7}{*}{ bakeries } & $18-25$ years & 2688 & 2,90 & 0,0000 \\
\hline & 26-35 years & 1490 & 2,90 & \\
\hline & $36-45$ years & 1156 & 2,99 & \\
\hline & $46-55$ years & 882 & 2,90 & \\
\hline & 56-65 years & 349 & 2,77 & \\
\hline & above 65 years & 239 & 2,73 & \\
\hline & sample & 6804 & 2,90 & \\
\hline \multirow{7}{*}{$\begin{array}{l}\text { beauty } \\
\text { providers }\end{array}$} & $18-25$ years & 2688 & 2,83 & 0,0014 \\
\hline & 26-35 years & 1490 & 2,89 & \\
\hline & $36-45$ years & 1156 & 2,90 & \\
\hline & $46-55$ years & 882 & 2,85 & \\
\hline & $56-65$ years & 349 & 2,69 & \\
\hline & above 65 years & 239 & 2,72 & \\
\hline & sample & 6804 & 2,85 & \\
\hline
\end{tabular}

Source: authors' own research 2020, N=6804, analysis of variance, measurement levels: nominal and metric scale

Since several studies have shown that consumer preferences and purchasing decisions are related to individual values [53], [54] we investigated whether the mindset and values of generations with different purchasing habits during the epidemic also carry this significant difference and to what extent individual value preferences can explain the difference in purchasing habits.

The survey also looked at respondents' values. The reason for investigating the value orientation is that many theories and behavioral models confirm that the consumer's purchase decision is ultimately based on the value orientation [55], [56]. 
Value system research has a crucial role in revealing the internal context of consumer behavior. It is no coincidence that the methods used in marketing research as early as the 1960s were based on the basic context of lifestyle and values, such as the AIO or the VALSI and VALSII methods [57]. The correlation between values and consumer behavior is also true for the analysis of food consumption and eating habits. This is evidenced by models that attribute dietary choices and food choices to values and lifestyle. A common feature of these models is that they start from abstract value systems of products or services and arrive at the specific attributes of a particular product, food or service in relation to these. Such is the case of Gutman's chain of meaning theory [58], which, as a hierarchical model, highlights the interrelationship between values, consumption and specific product attributes. According to the values-based food consumption behavior theory, the influence of values on food consumption preferences is realized at three levels [59]. At the first level are the general core values of the consumer, such as peace, security and time. At the second level are the values that determine consumer behavior, such as quality consciousness, hedonism and time consciousness. These reflect the social status, preferences and living conditions of the consumer. Finally, at the third level, there are the values of specific products and services, such as product and service choice motives [60]. A common feature of these theories is that they assume a relationship between the consumer's motives for product and service choice and the value system. These theories have inspired us to analyze each generation in terms of their value judgements in addition to their purchasing preferences, thus providing a more nuanced picture of the real reasons behind their consumer choices.

Significant differences $(\operatorname{sig}<0.005)$ were also found between the generations for each value dimension, with the only exception being the value of thrift (sig=0.011). (Hypothesis $\mathrm{H} 2 / \mathrm{b}$ confirmed). We believe that the difference in consumption and purchasing habits may be explained not only by the epidemic but also by the difference in values between generations. Analyzing the value orientation of each generation in the light of the results, we found that Generation $\mathrm{Z}$ members, above the sample average, value freedom to indulge in something good, plenty of free time, a career, hobbies, a good life and good human relations. Given this value orientation, it is not surprising that this generation is the one that has seen the highest levels of shopping activity for product groups and services in large shopping centers, small grocery stores and restaurants. Thus, it can be said that the highly individualistic values of young people are also linked to the high levels of shopping activity they have shown during the viral situation. This contrasts with respondents over 46, who tend to be more restrained in their spending, and whose values are more characterized by social sensitivity, pleasure for others and a desire for inner harmony. 
Table 5

Relationship between value orientation and age $\mathrm{e}^{4}$

\begin{tabular}{|c|c|c|c|c|}
\hline & & $\mathrm{N}$ & Average & sig \\
\hline \multirow[t]{7}{*}{ freedom } & 18-25 years & 2688 & 3,41 & 0,000 \\
\hline & 26-35 years & 1490 & 3,21 & \\
\hline & $36-45$ years & 1156 & 3,20 & \\
\hline & 46-55 years & 882 & 3,28 & \\
\hline & 56-65 years & 349 & 3,23 & \\
\hline & above 65 years & 239 & 3,24 & \\
\hline & sample & 6804 & 3,30 & \\
\hline \multirow[t]{7}{*}{ giving pleasure to others } & 18-25 years & 2688 & 3,18 & 0,000 \\
\hline & 26-35 years & 1490 & 3,09 & \\
\hline & $36-45$ years & 1156 & 3,06 & \\
\hline & $46-55$ years & 882 & 3,23 & \\
\hline & 56-65 years & 349 & 3,19 & \\
\hline & above 65 years & 239 & 3,15 & \\
\hline & sample & 6804 & 3,14 & \\
\hline \multirow{7}{*}{$\begin{array}{l}\text { I can afford something } \\
\text { good }\end{array}$} & 18-25 years & 2688 & 3,19 & 0,000 \\
\hline & 26-35 years & 1490 & 3,07 & \\
\hline & $36-45$ years & 1156 & 3,05 & \\
\hline & 46-55 years & 882 & 3,11 & \\
\hline & 56-65 years & 349 & 3,08 & \\
\hline & above 65 years & 239 & 3,00 & \\
\hline & sample & 6804 & 3,12 & \\
\hline \multirow[t]{7}{*}{ peaceful life } & $18-25$ years & 2688 & 3,38 & 0,000 \\
\hline & 26-35 years & 1490 & 3,22 & \\
\hline & $36-45$ years & 1156 & 3,28 & \\
\hline & 46-55 years & 882 & 3,42 & \\
\hline & $56-65$ years & 349 & 3,45 & \\
\hline & above 65 years & 239 & 3,23 & \\
\hline & sample & 6804 & 3,33 & \\
\hline \multirow[t]{7}{*}{ health } & 18-25 years & 2688 & 3,47 & 0,000 \\
\hline & 26-35 years & 1490 & 3,30 & \\
\hline & $36-45$ years & 1156 & 3,32 & \\
\hline & $46-55$ years & 882 & 3,44 & \\
\hline & $56-65$ years & 349 & 3,46 & \\
\hline & above 65 years & 239 & 3,35 & \\
\hline & sample & 6804 & 3,40 & \\
\hline
\end{tabular}

\footnotetext{
${ }^{4}$ average where 1 = greatly decreased, 4 = greatly increased
} 
Á. Csiszárik-Kocsir et al. What has Become Important during the Pandemic? - Reassessing Preferences and Purchasing Habits as an Aftermath of the Coronavirus Epidemic through the Eyes of Different Generations

material well-being

\begin{tabular}{lrrr} 
18-25 years & 2688 & $\mathbf{3 , 2 4}$ & 0,000 \\
\hline 26-35 years & 1490 & 3,14 & \\
\hline 36-45 years & 1156 & 3,14 & \\
\hline 46-55 years & 882 & 3,17 & \\
\hline 56-65 years & 349 & 3,19 & \\
\hline above 65 years & 239 & 3,05 & \\
\hline sample & 6804 & 3,18 & \\
18-25 years & 2688 & $\mathbf{3 , 1 6}$ & 0,000 \\
\hline 26-35 years & 1490 & 3,10 & \\
\hline 36-45 years & 1156 & 3,01 & \\
\hline 46-55 years & 882 & 3,06 & \\
\hline 56-65 years & 349 & 3,00 & \\
\hline above 65 years & 239 & 2,90 & \\
\hline sample & 6804 & 3,09 &
\end{tabular}

calm, balanced family
life

18-25 years

$2688 \quad 3,44 \quad 0,000$

26-35 years 1490

$1490 \quad 3,30$

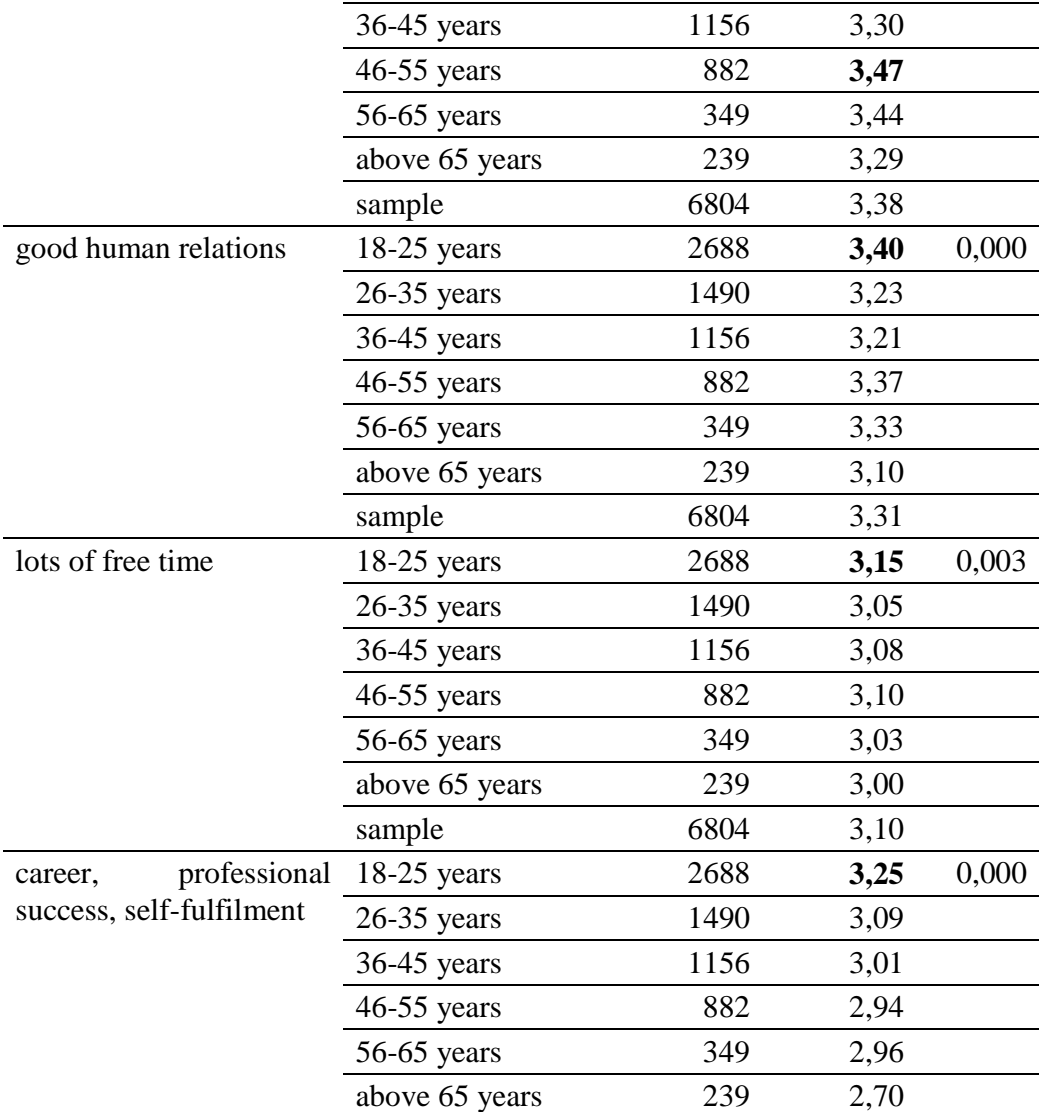




\begin{tabular}{|c|c|c|c|c|}
\hline & sample & 6804 & 3,10 & \\
\hline \multirow[t]{7}{*}{ inner harmony } & $18-25$ years & 2688 & 3,37 & 0,000 \\
\hline & $26-35$ years & 1490 & 3,24 & \\
\hline & $36-45$ years & 1156 & 3,25 & \\
\hline & $46-55$ years & 882 & 3,38 & \\
\hline & $56-65$ years & 349 & 3,36 & \\
\hline & above 65 years & 239 & 3,29 & \\
\hline & sample & 6804 & 3,32 & \\
\hline \multirow[t]{7}{*}{ happy family life } & $18-25$ years & 2688 & 3,47 & 0,000 \\
\hline & $26-35$ years & 1490 & 3,28 & \\
\hline & $36-45$ years & 1156 & 3,35 & \\
\hline & 46-55 years & 882 & 3,45 & \\
\hline & 56-65 years & 349 & 3,49 & \\
\hline & above 65 years & 239 & 3,25 & \\
\hline & sample & 6804 & 3,40 & \\
\hline \multirow[t]{7}{*}{ enjoyable life } & $18-25$ years & 2688 & 3,42 & 0,000 \\
\hline & $26-35$ years & 1490 & 3,23 & \\
\hline & $36-45$ years & 1156 & 3,21 & \\
\hline & $46-55$ years & 882 & 3,24 & \\
\hline & 56-65 years & 349 & 3,10 & \\
\hline & above 65 years & 239 & 2,95 & \\
\hline & sample & 6804 & 3,29 & \\
\hline
\end{tabular}

Source: authors' own research 2020, N=6804, analysis of variance, measurement levels: nominal and metric scale

\section{Summary}

In conclusion, our results show that the impact of the coronavirus has changed consumer habits and the composition of the consumer basket: the service sector has incurred the biggest losses due to the pandemic as it has seen a decline in every industry we have studied, according to the responses of our respondents. However, there are significant differences in the purchasing activity of each generation, both in consumer goods and services. Generation $\mathrm{Z}$ showed the strongest consumption activity in the consumer goods sector during the epidemic, while the same was true for Generation X in the tertiary sector. Differences in consumer preferences are also related to individual values. The values of Generation $\mathrm{Z}$, which was the least restrained in its consumption in the wake of the virus, also carry strongly individualistic, hedonistic traits. While the generation over 45 , which is typically more restrained in its spending and more frugal and active in its spending at the outbreak of the virus, is characterized by traditional values and social sensitivity, which also explains its purchasing behavior. The results of the research show that generationspecific buying and consumption patterns are also related to individual values. This result also provides useful information in practical terms, as it allows a more sophisticated understanding of the differences in purchasing and consumption 
preferences between generations, which can help design target group-oriented activities and modify the service and product purchasing preference system.

\section{References}

[1] O’Rourke, K. \& Williamson, J. G.: When did globalization begin? European Review of Economic History, 2002, 6(1), pp. 23-50, doi:10.1017/S1361491602000023

[2] Awdel, M., Odel, M. \& Saadi, F.: The rise of the globalization and its effect ont he autonomy of state and political economy. Journal of Critical Reviews, 7(6) 2020

[3] Dao, D.: Globalisation and state power: The question of context. The ANU Undergraduate Research Journal, 2014, pp. 63-72

[4] Moore, P. M.: The Decisions Bridging the GATT 1947 and the WTO Agreement. American Journal of International Law, 2017, 90(2) pp. 317328, doi: $10.2307 / 2203695$

[5] Contractor, F.: The world economy will need even more globalization in the post-pandemic 2021 decade. Journal of International Business Studies, 1 February, 2021

[6] Jaworek, M. \& Kuzel, M.: Transnational corporations in the world economy: Formation, development and present position. Copernican Journal of Finance and Accounting., 2015, 4(1) pp. 55-70

[7] UNCTAD: The World Investment Report 2020 [https://unctad.org/webflyer/world-investment-report-2020]

[8] Kyove, J., Streltsova, K., Odibo, U. \& Cirella, G. T.: Globalization Impact on multinational enterprises. World 2021, 2(2), pp. 216-230

[9] Michałowska, M. \& Danielak, W.: The Impact of Globalization on Consumer Behavior in Lubuskie Province in the Light of the Research. July 2015 https://www.researchgate.net/publication/282519972_The_Impact_ of_Globalization_on_Consumer_Behavior_in_Lubuskie_Province_in_the_ Light_of_the_Research

[10] Ger, G. \& Belk, R. W.: Cross-cultural differences in materialism, Journal of Economic Psychology, 1996, Vol. 17, pp. 55-77

[11] Chauhan, V.: Globalization and its Impact on Indian Consumer Behavior. Business and Economics Journal, 2021, Vol 12: S1

[12] Paliwoda, S. \& Slater, S.: Globalization through the kaleidoscope. International Marketing Review, 2009, 26, pp. 373-383

[13] Cleveland, M., \& Laroche, M.: Acculturation to the global consumer culture: Scale development and research paradigm. Journal of Business Research, 2007, 60(3), pp. 249-259, https://doi.org/10.1016/j.jbusres.2006.11.006 
[14] Arnould, E. J. \& Thompson, C. J.: Consumer Culture Theory (CCT): Twenty years of research. Journal of Consumer Research,2005, 31, pp. 868-882

[15] Kotler, P. \& Keller: Marketingmenedzsment, Akadémia Kiadó, 2012

[16] Schiffman L. \& Kanuk L. L.: Consumer Behavior, Prentice Hall, 2000, 469

[17] Schiffman, L. B., Cowley, D., Cass, E., Watson, A. O., Kanuk, J. \& Kanuk L.: Consumer Behavior ( $2^{\text {nd }}$ Edition) Australasian Marketing Journal 2001, $9(1)$

[18] Berndt, R.: Marketing 1: Käuferverhalten, Marktforschung und MarketingPrognosen. Springer-Lehrbuch, Tübingen, 1990, pp. 44-65

[19] McKinsey: How COVID-19 is changing consumer behavior - now and forever, Research paper, McKinsey Global Institute, 2020

[20] [https://www.mckinsey.com/ /media/mckinsey/industries/retail/our\%20insi ghts/how\%20covid\%2019\%20is\%20changing\%20consumer\%20behavior\% 20now\%20and\%20forever/how-covid-19-is-changing-consumerbehaviornow-and-forever.pdf]

[21] Sheth, J.: Impact of Covid-19 on consumer behavior: Will the old habits return or die? Journal of Business research, 2020, Vol. 117, pp. 280-283

[22] Laato, S., Islam, A. K. M. N., Farooq, A. \& Dhir, A.: Unusual purchasing behavior during the early stages of the COVID-19 pandemic: The stimulusorganism-response approach. Journal of Retailing and Consumer Services, 2020, Vol. 57

[23] Svajdova, L.: Consumer behaviour during pandemic of COVID-19. Journal of International Business Research and Marketing. 2021, 6(3) pp. 34-37

[24] Hesham, F., Riadh, H. \& Sihem, N. K.: What have we learned about the effects of the COVID-19 Pandemic on consumer behavior? Sustainability, 2021, 13(8)

[25] Mehta, S., Saxena, T. \& Purohit, N.: The new consumer behavior paradigm amid COVID-19: Permanent or transient? Journal of Health Management, 2020, 22(2) pp. 291-301

[26] Flatters, P., \& Willmott, M.: Understanding the post-recession consumer. Harvard Business Review, 2009, 106-112 (July-August)

[27] Töröcsik, M. \& Csapó, J.: A nemfogyasztás/nemvásárlás motivációi, értelmezése a turizmusban. Vezetéstudomány, 2021, 52 (1), pp. 42-55

[28] Chronopoulos, D. K., Lukas, M. \& Wilson, J. O. S.: Spending Responses to the COVID-19 Pandemic: An Assessment of Great Britain, Enterprise Research Centre, UK., 2020 
Á. Csiszárik-Kocsir et al. What has Become Important during the Pandemic? - Reassessing Preferences and Purchasing Habits as an Aftermath of the Coronavirus Epidemic through the Eyes of Different Generations

[29] Baker, S. R., Bloom, N., Davis, S. J., Kost, K., Sammon \& M., Viratyosin, T.: The Unprecedented Stock Market Reaction to COVID-19. National Bureau of Economic Research Working Paper, 2020, No. 26945

[30] Baker, S. R., Bloom, N., Davis, S. J. \& Terry, S. J.: COVID-Induced Economic Uncertainty, National Bureau of Economic Research Working Paper, 2020, No. 26983

[31] Baker, S. R., Farrokhnia, R. A., Meyer, S., Pagel, M. \& Yannelis, C.: How Does Household Spending Respond to an Epidemic? Consumption during the 2020 COVID-19 Pandemic, National Bureau of Economic Research Working Paper, 2020, No. 26949

[32] BCG: COVID-19 consumer sentiment snapshot: Fighting in the dark. Boston Consulting Group e-book. April 6, 2020 [https://www.bcg.com/publications/2020/covid-consumer-sentimentsurvey-snapshot-11-20-20]

[33] KPMG: Embedding resilience. Research paper of KPMG. March, 2020 https://home.kpmg/xx/en/home/insights/2020/04/covid-19-a-guide-tomaintaining-enterprise-resilience.html

[34] Accenture: How COVID-19 will permanently change consumer behavior? Research paper, 2020 [https://www.accenture.com/_acnmedia/PDF134/Accenture-COVID19-Consumer-Behaviour-Survey-ResearchPoV.pdf]

[35] Hassen, T. B., Bilali H. E., Allahyari, M. S., Berjan, S. \& Forina, O.: Food purchase and eating behavior during the COVID-19 pandemic: A crosssectional survey of Russian adults. Appetite, 2021, 165(1)

[36] Janssen, M., Chang, B., Hristov, H., Pravst, I., Profeta, A. \& Millard, J.: Changes in food consumption during the COVID-19 pandemic: Analysis of consumer survey data from the first lockdown period in Denmark, Germany, and Slovenia. Frontiers in Nutrition. 8 March, 2021

[37] Sayyida, S., Hartini, S., Gunawan, S. \& Nur Husin, S.: The impact of the covid-19 pandemic on retail consumer behavior 5(1). Aptisi Transactions on Management, 2021, pp. 79-88

[38] Törőcsik, M.: Fogyasztói magatartás - Trendek. KJK, Budapest, 2003

[39] Coupland, D.: X generáció. Európa Könyvkiadó, Budapest. 2007

[40] Törőcsik, M., Szücs, K. \& Kehl, D.: Generációs gondolkodás - A Z és az Y generáció életstílus csoportjai, Marketing \& Menedzsment, 2014, II. különszám, pp. 3-15

[41] Parment, A.: Generation Y vs. Baby Boomers: Shopping behavior, buyer involvement and implications for retailing, Journal of Retailing and Consumer Services, 2013, 20(2), pp. 189-199 
[42] Lipowski, M.: The differences between generations in consumer behavior in the service sales channel, Annales Universitatis Mariae Curie-Skłodowska, Sectio H Oeconomia 2017, LI/2017. No. 2, pp. 159-167

[43] Müller, Zs.: Kereskedelem és fogyasztói piacok 2018 - Fogyasztói mozgatóerők, KMPG Kutatása, 2018

[44] Tari, A.: Y generáció - Klinikai pszichológiai jelenségek és társadalomlélektani összefüggések az információs korban, Jaffa Kiadó, Budapest, 2010

[45] Nógrádi-Szabó, Z. \& Neulinger, Á.: Értékek és életmód generációs megközelítésben: a Z generáció. EMOK Tanulmányok, 2017 https://emok.hu/tanulmany-kereso/d534:ertekek-es-eletmod-generaciosmegkozelitesben-a-z-generacio

[46] Pruša, P. \& Sadílek, T.: Green Consumer Behavior: The Case of Czech Consumers of Generation Y. Social Marketing Quarterly, 2019, 25(4) pp. 243-255

[47] Guven, O.: Millennial (Gen Y) Consumer Behavior Their Shopping Preferences and Perceptual Maps Associated With Brand Loyalty, Canadian Social Science, 2015, 11(4) pp. 40-55

[48] Chakraborty, T. \& Balakrishnan, J.: Exploratory tendencies in consumer behavior in online buying across gen $\mathrm{X}$, gen $\mathrm{Y}$ and baby boomers, International Journal of Value Chain Management, 2017, 8(2) pp. 135-150

[49] Donghyun, K. \& Ammeter, P. A.: Shifts in online consumer behavior: a preliminary investigation of the net generation. Journal of Theoretical and Applied Electronic Commerce Research, 2021, 13(1) pp. 1-25

[50] Prensky, M.: Digital Natives, Digital Immigrants Part 1, On the Horizon. MCB University Press, 2001, 9 (5) pp. 1-6

[51] Magasvári, A. \& Szilágyi, T.: Z generációs pénzügyi nyomozók munkával kapcsolatos elvárásai, In: Biztonság, szolgáltatás, fejlesztés, avagy új irányok a bevételi hatóságok müködésében. Magyar Rendészettudományi Társaság Vám- és Pénzügyőri Tagozat, Budapest, 2019, pp. 142-156

[52] Sajtos, L. \& Mitev, A.: SPSS kutatási és adatelemzési kézikönyv, SPSS Research and Data Analysis Manual Budapest. Alinea Kiadó, 2007

[53] Huang, J. J., Tzeng, G. H. \& Ong, C. S.: Multidimensional data in multidimensional scaling using the analytic network process. Pattern Recognition Letters, 2005, 26(6), pp. 755-767

[54] Csiszárik-Kocsir, Á., Garai-Fodor, M.: Why is it important to learn finances? Results based on the opinion of $\mathrm{z}$ generation, Business Excellence, 2018, 12(2), pp. 41-58 
[55] Garai-Fodor, M., Csiszárik-Kocsir, Á.: Validity of value-based consumer behaviour models in terms of the financial awareness of Generations $\mathrm{Z}$ and Y, Public Finance Quarterly 2018, 4, pp. 511-529

[56] Coney, K.: Consumer Behavior $5^{\text {th }}$ ed. Irwin, Boston M. A., 1992, In: Hofmeister-Tóth Á.: Fogyasztói magatartás Budapest: Aula Kiadó, 2003, 325

[57] Horváth, Á., Fürediné, K. A. \& Fodor, M.: Az értékrend hatása a táplálkozásra. Élelmiszer, Táplálkozás és Marketing II, 2005 (1-2) 69-77

[58] Veres, Z.: A szolgáltatásmarketing alapkönyve, Akadémiai Kiadó, 2009

[59] Lehota J. (ed): Élelmiszergazdasági marketing, Budapest: Műszaki Kiadó, 2001, 323

[60] Grunert, K. G.: Food quality and safety: Consumer perception and demand, European Review of Agricultural Economics, 2005, 32, 369-391

[61] Horváth, Á.: A fogyasztói magatartás és az élelmiszerfogyasztás jellemzői. (PhD) Doktori értekezés, GATE, Gödöllő, 1996

[62] Berndt, R.: Marketing 1: Käuferverhalten, Marktforschung und MarketingPrognosen. Springer-Lehrbuch, Tübingen, 1990, pp. 44-65

[63] Mehta, S., Saxena, T. \& Purohit, N.: The new consumer behavior paradigm amid COVID-19: Permanent or transient? Journal of Health Management, 2020, 22(2) 291-301 